\title{
Views of Academic Staff in Universities on Lifelong Learning and Adult Education
}

\author{
Berna Karakoc \\ Dr, Kilis 7 Aralik University, Physical Education and Sports Academy, Kilis, Turkey. \\ Email:bernakarakoc@gmail.com Tel: +903488142666/1773
}

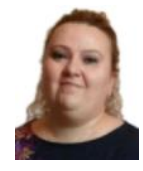

\begin{abstract}
The general aim of this study is to find out the views of academic staff working at universities on lifelong learning and adult education. While finding out the views of academic staff, the 6 principles of Andragogy Approach, which includes the characteristics of adults about learning, were taken as basis and the professional or personal development trainings academic staff received were analysed separately within the framework of these principles. Interview technique, one of the most frequently used in qualitative research methods, was used in the study. Interviews were made with a total of 20 academic staff who had received training within the scope of adult education and lifelong learning. The interviews were recorded with a voice recorder and transcribed. The transcribed data were evaluated with descriptive analysis method and then they were coded. Interpretations were made by using the codes. As a result, it was found that the academic staff in general had received education on lifelong learning and adult education voluntarily and it was concluded that they received these trainings for professional or personal development, to increase their quality of life, to gain experience, to advance academically and for similar reasons.
\end{abstract}

Keywords: Lifelong learning, Adult education, Andragogy, Andragogical principles, Adult, Academic staff in universities.

Citation | Berna Karakoc (2021). Views of Academic Staff in Universities on Lifelong Learning and Adult Education. Asian Journal of Education and Training, 7(3): 195-203.

History:

Received: 15 June 2021

Revised: 20 July 2021

Accepted: 17 August 2021

Published: 6 September 2021

Licensed: This work is licensed under a Creative Commons

Attribution 3.0 License (cc) E

Publisher: Asian Online Journal Publishing Group
Funding: This study received no specific financial support.

Competing Interests: The author declares that there are no conflicts of interests regarding the publication of this paper.

Transparency: The author confirms that the manuscript is an honest, accurate, and transparent account of the study was reported; that no vital features of the study have been omitted; and that any discrepancies from the study as planned have been explained.

Ethical: This study follows all ethical practices during writing.

\section{Contents}

1. Introduction

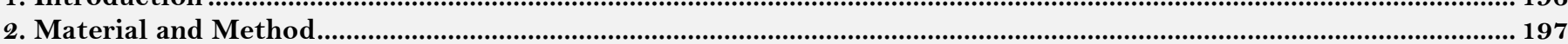

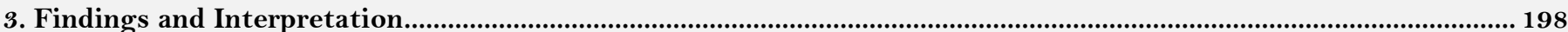

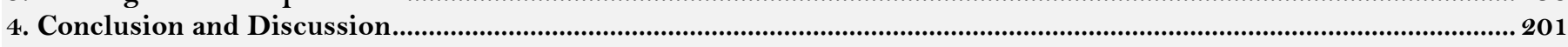

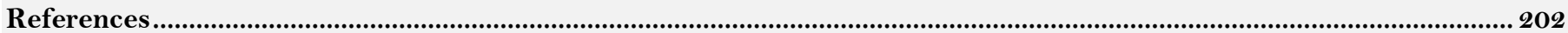




\section{Contribution of this paper to the literature}

This study contributes to existing literature by finding out the views of academic staff working at universities on lifelong learning and adult education.

\section{Introduction}

Today, the social importance of adult education and lifelong learning is increasing day by day. It has become important for all segments of society to follow and keep up with the changes in many areas such as information and communication, digitalization, technology and education (Commission of the European Communities, 2000; İliç \& Haseski, 2019). In order to adapt to this change, individuals need to develop themselves throughout their lives, rather than just sticking to the formal education process (Allmendinger et al., 2019). In general, children and young people come to mind first when the concepts of education and training are mentioned. However, the concepts of education and have ceased to be concepts considered separately for all age groups and gaining awareness of the need for lifelong learning and learning at all ages, placing the necessary importance on adult education and organizing training by being aware of the basic needs of adults have begun to be considered (Kara \& Karakoç, 2017).

Education is no longer something that only young people will benefit from; on the contrary, due to the increasing need of countries for qualified workers, lifelong learning and adult education have become more important. One way for meeting this demand for qualified workers is educating adults more (OECD, 2012). Since lifelong learning is associated with individuals' education and professional careers, it takes place through adults' participation in trainings through organizing their families, professional careers, time and economy (Commission of the European Communities, 2000). Thus, adults who are in a constant development and change all through their lives also develop their learning experiences in this process. These trainings, which take place at every stage of our lives and include all people and which are generally carried out under the name of adult education, are called and applied with different concepts such as staff development, developmental training, in-service training, on-going education, lifelong education (Knowles, 1980), and lifelong learning has become an indispensable part of individuals' existing and future education careers.

Adult education is concerned with the fact that adults have different characteristics than children and young people and with how these characteristics should be reflected to the learning process. These differences also include the psychological characteristics of adults that are different from children and young people and the social and cultural characteristics that include the expectations of the society from them. In this direction, Knowles introduced us to the concepts of andragogy and pedagogy and stated that the learning and development of adults were different from children's. Pedagogy is the science and art of educating children, while andragogy is the science and art of helping adults to learn. According to the andragogy approach, which is developed by Knowles and defined as the science and art of helping adults to learn, the andragogical model which plays an important role in adults' learning is based on six principles (Knowles \& Ayhan, 1996; Knowles, Holton III, \& Swanson, 2005):

1-The learner's need to know: Adults need to learn why they should learn something before they learn it. The effectiveness of adults' performances and the increase in their quality of life will facilitate their learning. Adults spend too much time on the benefits they will derive from learning something or what negative consequences may occur when they do not learn it.

2-Self-directedness: Adults have a sense of self to take responsibility for their own decisions and their lives. They want others to see that they have the ability to manage themselves. Their psychological maturing causes changes in which they begin to manage themselves without being dependent on others. Therefore, when we start treating them like children, this creates a problem.

3- The role of experience: Adults come to an educational activity with higher and more diverse experience than young people. This has various consequences for adult education. One of these is the fact that adults who participate in the education show more individual differences than young people. Another one is that the learning ways, motivations and past experiences of any group of adults are different from a group of young people.

4- Readiness to learn: Adults come ready to learn since they know what they need and they can cope with their own real life situations.

5-Orientation to learning: Unlike children and young people, adults' orientation to learning is life-centred. Adults learn new knowledge, skills, values and attitudes most effectively when they can apply them to real life situations.

6-Intrinsic motivation: While some extrinsic motivations of adults (job, promotion, higher salary) are insignificant reasons for education, the most effective motivators are intrinsic motivations (job satisfaction, selfrespect, quality of life, etc.)

Adults need to develop themselves to find jobs with better conditions, to get better opportunities in their professional life or to get promotion in their jobs. During the learning process, they can share their thoughts and their ideas about the equipment and methods to be used with the teacher. They can determine the method suitable for them and present to the teacher. They can evaluate teachers' ways of teaching the subjects and tell their choices. When considered this way, adults are an important source of information about the functioning of the teaching process from the beginning to the end (Hisar, 2006). When the literature was reviewed, studies were found on both adult education and lifelong learning. There are also studies which discuss and evaluate the views of academic staff in universities on adult education and lifelong learning (Ayçiçek \& Yelken, 2016; Edokpolor \& Omiunu, 2017; Konokman, Akay, \& Demircioğlu, 2015; Mora, 2001; Walczak \& Kálmán, 2018; Yildrim \& Akcay, 2017; Zhou \& $\mathrm{Tu}, 2019)$. The views of academic staff working in universities on lifelong learning and adult education were found in this study. However, this study is different from other studies in that the evaluations were based on the 6 principles of Andragogical Approach including adults' characteristics on learning which were created for consideration in adult education by Knowles, who is one of the leading names of adult education. In this context, the overall aim of our study is to show the views of academic staff working in universities on lifelong learning and adult education. While showing the views of adults, Knowles et al. (2005) 6 principles of Andragogical Approach 
including adults' characteristics on learning were taken as basis and the trainings academic staff received in terms of their professional or personal development were analysed separately within the framework of these principles.

\section{Material and Method}

Information about the method, study group, data collection and data collection instruments of the study were included in this part.

\subsection{Research Method}

Qualitative research method was used in the study. Interview technique, one of the most frequently used in qualitative research methods, was used in the study and the data were analysed with descriptive analysis technique. Different characteristics of qualitative research techniques are describing a phenomenon within its natural environment, providing sensitivity, giving the researcher a participating role, having an integrative approach, showing the perceptions and emotions of the participants and having a flexible research design (Yıldırım \& Simşek, 2013). In addition, qualitative designs are natural since they are conducted in the daily life areas of researches and the researcher does not attempt to change this natural environment. Interviews are made in places where individuals know and are comfortable with by using open ended questions (Patton, 2014).

\subsection{Research Group}

In the study, interviews were made with a total of 20 academic staff who had received training on adult education and lifelong learning. The participants were reached by choosing convenience sample in determining the academic staff included in the research group. In convenience sampling method, the aim is to bring speed and practicality to the study (Yıldırım \& Simşek, 2013). Each academic staff was expressed with a number, not with their names. For example, "1" represents the academic staff numbered 1. The distribution of the academic staff who were interviewed in terms of some variables and information about each are shown in two different tables below.

\begin{tabular}{l|l|c|c}
\multicolumn{4}{c}{ Table-1. Distribution of the academic staff interviewed in terms of some variables } \\
\hline Variable & Male & Number of academic staff & $\%$ \\
\hline \multirow{3}{*}{ Gender } & Female & 5 & 25 \\
\hline \multirow{4}{*}{ Age } & $30-40$ & 15 & 75 \\
\cline { 2 - 4 } & $41-50$ & 14 & 70 \\
\cline { 2 - 4 } & 51 and older & 5 & 25 \\
\hline \multirow{5}{*}{ Working years } & $1-5$ years & 1 & 5 \\
\cline { 2 - 4 } & $6-10$ years & 1 & 20 \\
\cline { 2 - 4 } & $11-15$ years & 4 & 40 \\
\cline { 2 - 4 } & $16-20$ years & 8 & 25 \\
\cline { 2 - 4 } & 21 years and higher & 5 & 10 \\
\hline \multirow{5}{*}{ Title } & Lecturer Dr. & 2 & 15 \\
\cline { 2 - 4 } & Lecturer & 4 & 25 \\
\cline { 2 - 4 } & Assist. Prof. Dr. & 3 & 10 \\
\cline { 2 - 4 } & Assoc. Prof. Dr. & 5 & \\
\cline { 2 - 4 } & Professor Dr. & 6 & 2 \\
\hline
\end{tabular}

Table-2. Information about the academic staff.

\begin{tabular}{c|l|c|l|l}
\hline Number of participants & Gender & Age & Year of study & Title \\
\hline 1 & Female & 35 & $11-15$ years & Research assistant Dr \\
\hline 2 & Female & 35 & $6-10$ years & Research assistant Dr \\
\hline 3 & Female & 33 & $11-15$ years & Research assistant Dr \\
\hline 4 & Female & 32 & $6-10$ years & Assist. Prof. Dr. \\
\hline 5 & Female & 33 & $11-15$ years & Research assistant Dr \\
\hline 6 & Female & 42 & $6-10$ years & Lecturer \\
\hline 7 & Female & 33 & $11-15$ years & Lecturer \\
\hline 8 & Female & 39 & $11-15$ years & Lecturer \\
\hline 9 & Male & 33 & $6-10$ years & Assist. Prof. Dr. \\
\hline 10 & Male & 37 & $1-5$ years & Assist. Prof. Dr. \\
\hline 11 & Male & 40 & $16-20$ years & Assist. Prof. Dr. \\
\hline 12 & Female & 38 & $11-15$ years & Assist. Prof. Dr. \\
\hline 13 & Male & 51 & $\geq 21$ years & Assoc. Prof. Dr. \\
\hline 15 & Female & 44 & $16-20$ years & Assoc. Prof. Dr. \\
\hline 16 & Female & 36 & $11-15$ years & Assoc. Prof. Dr. \\
\hline 17 & Female & 34 & $11-15$ years & Assoc. Prof. Dr. \\
\hline 18 & Male & 45 & $16-20$ years & Assoc. Prof. Dr. \\
\hline 19 & Female & 42 & $\geq 21$ years & Assoc. Prof. Dr. \\
\hline 20 & Female & 41 & $16-20$ years & Professor Dr. \\
\hline & Female & 43 & $16-20$ years & Professor Dr. \\
\hline
\end{tabular}

When Table 1 is examined, when the academic staff who participated in the study were analysed on adult education and lifelong education in terms of the variable of gender, it can be seen that 15 were female $(75 \%)$, while $5(25 \%)$ were male. In terms of the variable of age, it was found that 14 of the participants were between $30-40$ 
years of age $(70 \%), 5$ were between $41-50$ years of age and 1 (5\%) participant was 51 and older. When evaluated in terms of years of working, it was found that 1 (5\%) participant was between 1-5 years, 4 (20\%) participants were between 6-10 years, 8 (40\%) participants were between 11-15 years, 5 (25\%) participants were between 16-20 years, and finally $2(10 \%)$ participants were between 21 years and higher. When the participants were analysed in terms of the variable of gender, it was found that $4(20 \%)$ participants were lecturer Dr., 3 (15\%) participants were lecturer, 5 (25\%) participants were assistant prof. Dr., 6 (30\%) participants were assoc. prof. Dr and 2 (10\%) participants were professor Dr.

Table 2 shows information about gender, age, working years and titles of the academic staff in the study.

\subsection{Data Collection Instrument}

While preparing the interview questions which constituted the data collection instrument of the study, first of all, a literature review was conducted. Drafted questions were turned into items and than, the items were eliminated and organized by taking the views of 3 experts. The final version was examined by linguists and the interview questions were finalized. The questions asked to academic staff in universities about lifelong learning and adult education are as follows:

1- What are your thoughts on "Lifelong learning"?

2- Considered within the framework of lifelong learning, have you ever needed any training for your professional development or personal development? If yes, why did you need this training?

3- Did you receive the training voluntarily, explain? Were there other factors that affected you in receiving this training, explain?

4- Did you have any previous experience about the training you received? If yes, what kind of contributions did this experience provide you with in the course you attended?

5- What are the contributions of the training you received to your real life (daily life, profession, etc..)?

6- What are the things that motivated you to receive this training?

The interview in general included questions about lifelong learning and the training academic staff received within the framework of andragogical principles. The answers given to questions were analysed and 7 different themes were determined as lifelong learning, need to know, self-directedness, role of experience, readiness, orientation to learning and motivation.

The theme of "lifelong learning" refers to academic staff's views on the topic; "need to know" theme refers to academic staff's knowing their insufficiencies in professional and personal development, "self-directedness" theme refers to whether it was their decision to receive education, "role of experience" theme refers to the contribution of their previous professional or personal information on the training they received, "readiness" theme refers to academic staff's knowing why they need education and being ready, "orientation to learning" theme refers to their orientation to learning and "motivation" theme refers to what motivate them to the education they received.

\subsection{Data Collection and Analysis}

Data collection instrument of the study consists of semi-structured interviews with academic staff. The interviews were made by using semi-structured method with each participant in March 2021. Academic staff participated in the interviews voluntarily and stated that they would answer the questions sincerely. The interviews were recorded with voice recorder. The records were transcribed. The transcribed data were evaluated with descriptive analysis method. In descriptive analysis, the data are placed under previously determined themes (Yıldırım \& Simşek, 2013). Next, the codes are created. The codes created were cross checked by two researchers and the agreement between codes was determined as approximately $92 \%$ and the study was considered to be reliable. Different codes were transformed into a common view, they were reviewed and a consensus was reached.

\section{Findings and Interpretation}

In the analysis of the qualitative data, the views of the academic staff on the training they received within the framework of lifelong learning and andragogical principles were arranged in a way that overlapped with the research questions. Tables were created from the themes, the coding of each academic staff's views, how many times the code was mentioned and example sentences of academic staff related with themes were examined Table 3 includes the views of academic staff on "Lifelong learning" theme.

\begin{tabular}{l|l|c|l}
\multicolumn{4}{c}{ Table-3. Interview analysis results of academic staff on "lifelong learning" theme. } \\
\hline Themes & Codes & F & Example sentence \\
\hline Lifelong & Opportunity to learn & 9 & It is a truth that learning continues for a life time. \\
learning & Personal development & 8 & It is usual and sometimes necessary for us to \\
& Obligation & 8 & receive compulsory or optional training, both in \\
& Need to learn & 8 & both in professional competence and personal \\
& Professional development & 7 & development. (2) \\
& Process & 5 & \\
& Updating & 3 & \\
& All kinds of learning activities & 1 & \\
\hline
\end{tabular}

In Table 3, "Lifelong learning" was determined as the first theme. This theme includes codes about the views of academic staff on lifelong learning. This theme was mentioned for a total of 49 times. In the interviews, opportunity to learn was mentioned 9 times, personal development was mentioned 8 times, obligation was mentioned 8 times, need to learn was mentioned 8 times, professional development was mentioned 7 times, process was mentioned 5 times, updating was mentioned 3 times, all kinds of learning activities was mentioned once. Example expressions in this context are given below.

"Lifelong learning" is in fact a process all of us are continually in consciously or unconsciously". (18)

"No matter at what age and regardless of educational level, an individual is part of lifelong learning". (8) 
"The obligation of following new things all the time due to my profession sometimes requires the necessity to receive professional training" (1)

In this context, it was found that the academic staff stated that learning is a process that continues for a life time, it provides them opportunity to learn and has become an obligation today. Table 4 includes the analysis of the views of academic staff on the theme "need to know".

Table-4. Interview analysis results of academic staff on "need to learn" theme.

\begin{tabular}{l|l|c|l}
\hline Themes & Codes & F & Example sentence \\
\hline \multirow{5}{*}{ Need to know } & Receiving education & 20 & I have received trainings and I am continuing to \\
& Obligation & 2 & do so. I need this to continue my profession \\
& Voluntariness & 2 & efficiently.(16) \\
& Completing deficiencies & 2 & I have received training because I want to follow \\
& Academic progress & 2 & new developments. (7) \\
& Insufficient previous knowledge & 1 & \\
& Professional efficiency & 1 & \\
& Following developments & 1 & \\
\hline
\end{tabular}

In Table 4, the second theme was determined as "Need to know". This theme included codes about academic staff's knowing about deficiencies in their professional or personal development and their thoughts about their reasons to develop these. This theme was mentioned for a total of 31 times. In the interviews, receiving education was mentioned 20 times, obligation was mentioned 2 times, voluntariness was mentioned 2 times, completing deficiencies was mentioned 2 times, academic progress was mentioned 2 times, insufficient previous knowledge was mentioned once, professional efficiency was mentioned once and following developments was mentioned once. Examples of academic staff's answers are given below.

"Yes, I have received. I have even received more than one training (except the ones during my postgraduate education. Project training (2018), qualitative research methods (2009), English education".(5)

"I received training on my professional development. I attended course to use... data analysis program. I needed this course because my doctoral thesis was mostly qualitative".(16)

In line with the views given by all academic staff, it was concluded that they received training since they knew about their professional or personal deficiencies and wanted to improve these within the context of need to know theme. Table 5 includes the analysis of the views of academic staff on "self-directedness" theme.

\begin{tabular}{l|l|c|l}
\multicolumn{2}{|c}{ Table-5. Interview analysis results of academic staff on "self-directedness" theme. } \\
\hline Themes & Codes & F & Example sentence \\
\hline \multirow{5}{*}{ Self- } & Voluntariness & 12 & Yes, I received this training voluntarily. My \\
directedness & Academic career & 5 & getting curious about the content of the training \\
& Orientation to learning & 5 & after my students received this training within a \\
& Obligation & 4 & course had an effect on my receiving the training. \\
& Professional development & 3 & $(15)$ \\
& Personal development & 1 & \\
& Feeling insufficient & 1 & \\
& Curiosity & 1 & \\
\hline
\end{tabular}

The third theme was determined as "self-directedness" in Table 5. This theme includes codes such as whether academic staff voluntarily received trainings or whether there were other factors that led them to receive the training. This theme was emphasized 32 times. Academic staff emphasized voluntariness 12 times, academic career 5 times, orientation to learning 5 times, obligation 4 times, professional development 3 times, feeling insufficient once, personal development once and curiosity once. Based on the emphases of academic staff, it was concluded that they received the training voluntarily. The following expressions were included.

"I received voluntarily; I even researched how I could receive training in this period". (18)

"I received training completely voluntarily because it would benefit me a lot about data analysis. This training was also useful for me to increase my academic knowledge". (3)

Although it was concluded from the expressions of the academic staff that it was their decision to receive these trainings, it was also concluded that they had to receive these trainings due to obligation, feeling insufficient or for their professional development.

"I received most of the trainings voluntarily for my professional and personal development. However, there were also trainings I received due to obligation". (11)

"I received Project training a few times. Two of these were voluntarily but the others were with the pressures of rectorate". (1)

Table 6 includes the analysis of academic staff's views on "role of experience" theme.

\begin{tabular}{l|l|c|c|c}
\multicolumn{1}{c}{ Table-6. Interview analysis results of academic staff on "role of experience" theme. } \\
\hline Themes & Codes & F & Example sentence \\
\hline \multirow{5}{*}{ Role of } & Theoretical background & 13 & I did not have any experience before. I \\
experience & Inexperience & 8 & wanted to get this training to gain \\
& Learning fast & 4 & experience. (2) \\
& Field-specific awareness & 4 & I did not have any experience before. \\
& Providing self-confidence & 2 & Thanks to it, in a very short time I accessed \\
& Motivation & 1 & information that I would search and access \\
& Adaptation & 1 & in long time myself. It provided me with \\
& Academic Progress & 1 & motivation. (1) \\
& Readiness & 1 & \\
\hline
\end{tabular}


In Table 6, the fourth theme was determined as "role of experience". This theme includes codes about whether academic staff had previous experience on the trainings they received and if they had, about its contribution to the training they received. This theme was emphasized 35 times. In this theme, the academic staff emphasized theoretical background 13 times, inexperience 8 times, learning fast 4 times, field-specific awareness 4 times, providing self-confidence 2 times, motivation once, adaptation once, academic progress once and readiness once. Most of the academic staff stated that they did not have any previous experience on the training they received. When analysed in this direction, it was concluded that although the academic staff did not have information about the training they received, some of them had theoretical knowledge. In this respect, academic staff numbered 6 said the following;

"I did not have any previous experience, but since I knew about the experiences theoretically, it was easier for me to understand and implement",

Academic staff numbered 17 said the following;

"Yes. I had participated in the seminars and courses in Turkey. I did not have any problems in the practice part of the course",

Academic staff numbered 19 said the following;

"Of course my background during my high school and university education had much contribution about adapting to the courses I attended and making the learning process faster",

Academic staff numbered 5 said the following;

"Yes, I did, but I did not think it was sufficient. My previous experiences helped as a background; it helped me to learn faster and easier. In addition, my previous knowledge provided me with some self-confidence while receiving this training"

When the previous experiences of academic staff on the trainings they received were examined, it was concluded that trainings provided them with learning faster, created field-specific awareness, gave them selfconfidence through previous experience, provided them with motivation and easier adaptation to training, helped them about academic progress and made them ready to learn. Table 7 includes the analysis of academic staff's views on "readiness" theme.

Table-7. Interview analysis results of academic staff on "readiness" theme.

\begin{tabular}{l|l|l|l}
\hline Themes & Codes & F & Example sentence \\
\hline \multirow{5}{*}{ Readiness } & Desire for self-improvement & 8 & \\
& Academic contribution & 8 & In terms of personal development, the trainings I \\
& Professional development & 6 & received in computer and English courses are very \\
& Curiosity & 3 & important in terms of both providing sufficiency in \\
& Cooperation & 2 & my profession and also in terms of learning new \\
& Practicality & 1 & concepts individually. (19) \\
& Professional responsibility & 1 & \\
& Insufficient postgraduate education & 1 & I received training to develop myself and learn a \\
& Lack of implementation & 1 & different approach.(6) \\
& Communication & 1 & \\
\hline
\end{tabular}

The fifth theme was determined as "Readiness" in Table 7.This theme includes codes about academic staff's knowing why they need the training they have received and being ready. Academic staff emphasized this theme 32 times. In this theme, academic staff emphasized desire for self-improvement 8 times, academic contribution 8 times, professional development 6 times, curiosity 3 times, cooperation 2 times, practicality once, professional responsibility once, postgraduate education once, lack of implementation once and communication once. In this theme, academic staff stated why they needed the training they received. Example sentences from academic staff are shown below.

"I received Project training from expert teams. The fact that I did not receive enough training about Project in postgraduate period and that I could not reflect this to implementations was a great insufficiency for me. This selfawareness pushed me to professional development program" (1)

"To develop professionally and to integrate theoretical information and implementation, to expand professional social network" (4)

"English course I received was very efficient. The reason why I needed it was the fact that I was responsible for English for my profession and my wish to have the information that I could need for my profession" (5)

Based on the explanations above, it was concluded that the academic staff knew about their deficiencies, they were willing to learn about what they needed and they were ready to learn. Table 8 includes the analysis of academic staff's views on "orientation to learning" theme.

Table-8. Interview analysis results of academic staff on "orientation to learning" theme.

\begin{tabular}{l|l|c|l}
\hline Themes & Codes & F & Example sentence \\
\hline \multirow{5}{*}{ Orientation } & Academic contribution & 16 & I think that the training I received made positive \\
to learning & Positive attitude & 8 & contributions to my personal and mental development in \\
& Professional development & 7 & addition to my professional development. (13) \\
& Gelf-confidence & 6 & I gained self-confidence. I began to research easier in my \\
& Personal development & 5 & profession. I transferred the information I learned to \\
& Ease of research & 3 & \\
& Providing international & 2 & \\
& communication & & \\
& Lack of knowledge & 2 & \\
& Mental development & 1 & \\
& Transfer of information & 1 & \\
& Socializing & 1 & \\
\hline
\end{tabular}


The sixth theme was determined as "orientation to learning" in Table 8. This theme included the codes about academic staff's views on orientation to learning. This theme was emphasized for 55 times. In this theme, academic staff emphasized Academic contribution 16 times, positive attitude 8 times, professional development 7 times, selfconfidence 6 times, gaining experience 5 times, personal development 3 times, ease of research 3 times, providing international communication 2 times, lack of knowledge 2 times, mental development once, transfer of information once and socializing once. Example sentences from academic staff are shown below.

Academic staff numbered 19:

"The contribution of these trainings to my professional development is very important in terms of realizing international working areas and strengthening communication in these areas in the continually changing ad globalizing world", Academic staff numbered 2:

"Professionally, I think that I learned data analysis and specific concepts and implementation in entering data", It was concluded that the academic staff thought the trainings they received contributed especially to their academic development, they gained experience and self-confidence and it provided ease of research. Table 9 includes the analysis of academic staff's views on "motivation" theme.

\begin{tabular}{l|l|c|l|l}
\hline \multicolumn{4}{|c}{ Table-9. Interview analysis results of academic staff on "motivation" theme. } \\
\hline Themes & Codes & F & Example sentence \\
\hline \multirow{5}{*}{ Motivation } & Professional progress & 7 & The rapid development of technology and science has \\
& Willingness to learn & 6 & always increased and made me realize my need for education \\
& Quality of life awscious & 6 & not only in this subject (drama), but also in other subjects. \\
& Extrinsic obligation & 4 & My goal in life is to provide personal development by \\
& Personal development & 3 & creating opportunities in learning, to ensure integration for \\
& Career planning & 2 & a contribution to society. In addition, leading my life in a \\
& Professional need & 2 & quality way has always motivated me in gaining knowledge \\
& Time management & 2 & and skills. (8) people from Turkey \\
& Experiencing & 1 & It was proud for me to be 1 of the 2 peom \\
& countries & 1 & since the education was given with scholarship. (17) \\
& Having been chosen & &
\end{tabular}

In Table 9, the seventh team was determined as "Motivation". This theme included codes about what motivated academic staff in the training they received. Academic staff emphasized this theme for a total of 36 times. The academic staff gave their views by emphasizing professional progress 7 times, willingness to learn 6 times, quality of life 6 times, conscious awareness 4 times, extrinsic obligation 3 times, personal development 2 times, career planning 2 times, professional need 2 times, time management once, experiencing different countries once, having been chosen once and social integration once. Example sentences from academic staff are shown below.

Academic staff numbered 11:

"My willingness to learn, my thoughts about academic progress and my career planning motivated me about getting these trainings".

Academic staff numbered 16:

"The thought that I would need this knowledge in my profession was my most important motivation". Academic staff numbered 3:

"My basic motivation in getting this training was need. It was important for me since I would use in my thesis. I can say that my secondary motivation was getting informed. I like learning new things".

It was concluded that what motivated academic staff in the training they received was to advance in their profession, to increase their quality of life and to contribute to their academic development, in addition to needing such training in terms of their personal and professional development and for getting help in career planning.

Academic staff numbered 12;

"There were no motivating elements since it was a compulsory training", Academic staff numbered 19;

"Such trainings which started as an obligation to meet professional competence have decreased my motivation" As can be understood from the expressions above, it was concluded that trainings did not provide motivation when they were received due to external obligation.

\section{Conclusion and Discussion}

In this study, the views of academic staff working in universities on lifelong learning and adult education were evaluated with semi-structured interview questions according to the trainings they received within the framework of andragogical principles. It was tried to examine the views of academic staff on the themes of; lifelong learning, need to know, self-directedness, role of experience, readiness, orientation to learning and motivation were analysed. As a result of the analyses, many different conclusions were made about the trainings that the academic staff received on lifelong learning and andragogical principles.

The academic staff were asked what their thoughts on "lifelong learning" were and it was found that in general they answered as lifelong learning is a process that continues from the beginning of human life to the end and humans needed to learn and continue to develop themselves all their lives. Kiran (2008) reached a similar conclusion in the study entitled "evaluation of public education centres in providing lifelong education" and stated that education is a process that continued for a lifetime. At the same time, it was stated in the study that receiving either compulsory or voluntary education provided them with learning opportunities and contributed to their professional development. Therefore, considering within the framework of lifelong learning, it can be interpreted that receiving education is important for academic staff's professional development and it may be because they want to keep their knowledge up-to-date all the time. Tam (2012) reached a similar conclusion in a study conducted on adults and stated that regardless of age and individuals' position, education, whether formal or informal, should be 
perceived as a process that continues lifelong in all learning environments. In a study conducted on prospective teachers, Kilıc (2014) concluded that teachers cared about lifelong learning and believed that creating learning opportunities in today's living conditions was necessary and important. In a study they examined the views of prospective teachers on lifelong learning and adult education course, İliç and Haseski (2019) found that prospective teachers' answers were related with mostly individual development and social development and after these on professional development and the importance of learning.

When considered within the framework of lifelong learning, all the academic staff answered the question of whether they needed any training for their professional or personal development with yes and it was concluded that they received training since they knew about the deficiencies in their professional or personal development. The fact that individuals want to develop themselves even after they start working can be interpreted as the necessity to renew knowledge and skills all the time in today's living conditions. About the question of their reasons for receiving these trainings, it was found that they stated their reasons as obligation, completing professional deficiencies, professional progress or following developments. Thus, it was concluded that the academic staff knew about their own deficiencies, they were willing to learn the things they needed and they were ready to learn in this case. Yazar (2012), who reached a similar conclusion with the study, stated that adult education is a broad concept which aims the social and professional development of adults and continues all through their lives.

Most of the academic staff answered the question of whether it was their own decision to receive education voluntarily as “yes". The results of Yayla (2009) in a study evaluating adult education system concluded that the rates of participation in in-service education seminars on adult education were low, which was not in parallel with the results of this study. As a result of the analysis of the expressions on whether there were other factors that guided them to receive these trainings, it was concluded that they had to receive these trainings as a result of obligation, desire to learn, wish to have academic career or professional development. In addition, personal development, feeling insufficient and curiosity are the other factors leading them to receive training. This can be interpreted as the fact that what led them to receive training was their wish to develop themselves professionally and academically although there were other reasons that led them to receive training.

In the analysis of the question about whether the academic staff had previous experience about the training they received, it was concluded that most of them had the theoretical background and some were inexperienced. When the contributions of previous experiences on the trainings they received were examined, it was found that they enabled the participants to learn faster, created field-specific awareness, provided them with self-confidence and motivation, helped them to better adapt to training, helped their academic progress and made them ready for learning. In a study which aimed to find out the experiences of adults who were in their thirties, Mali (2017) found that what supported adults' learning and increased their learning motivation and self-confidence was having previous life experience, which was similar to the results of the present study. This can be interpreted as adults' having previous knowledge about the topic they receive training for increasing their motivation and selfconfidence.

In the analysis of the question of what contributions the training they received made to their real lives, it was concluded that most of the academic staff thought it contributed to their academic knowledge, which created selfconfidence in them and made them develop positive attitude towards learning. In a study which aimed to show the role of public education centres in lifelong education during information society process, Kiran (2008) found that adult education affected learning positively as a result of meeting their expectations, which is in parallel with the results of this study. The results of Mali (2017) that the trainings received had a negative effect since the adults had to take care of their families and earn money and had limited time, which is not in parallel with the results of this study. Other results of this study are that they had the opportunity to share their information, to research more easily on their field and to make up for their deficiencies due to the trainings they received. Kıran (2008)'s result that the most important reason why they participated in courses was to "renew their knowledge and themselves $(86.5 \%)$ " is in parallel with the results of this study.

In the analysis of the question about what motivated academic staff for the trainings they received, it was found that the motivations were in general professional advancement, increasing their quality of life, the fact that these trainings contributed to their academic development, they were important in terms of personal development and they helped for career planning. Other motivating factors are academic staff's desire to see different countries and receiving these trainings by planning their time left from work and home life. In their study they aimed to examine the difficulties adults encountered while learning English as a second language, Wu and Wu (2014) reached a similar conclusion, they stated that adults learned better when they coordinated their family relationships, and planned time for working and learning. They also stated that adults' desire to learn new things motivated them and made them work more. This is similar to the result that one of the things motivating academic staff in the education they received is their desire to learn. Another result of this study is that trainings do not provide motivation for academic staff when it is compulsory to attend these trainings.

\section{References}

Allmendinger, J., Kleinert, C., Pollak, R., Vicari, B., Wölfel, O., Althaber, A., . . Janik, F. (2019). Adult education and lifelong learning. In Education as a Lifelong Process; Blossfeld, H.-P., Roßbach, H.-G., Eds (Vol. 3, pp. 325-346). Wiesbaden, Germany: Springer Fachmedien Wiesbaden.

Ayçiçek, B., \& Yelken, T. Y. (2016). Investigation of lifelong learning competencies and life-wide learning habits of faculty members in education faculties. Journal of Mersin University Faculty of Education, 12(3), 872-884.

Commission of the European Communities. (2000). A memorandum on lifelong learning. Brussels: Commission of the European Communities.

Edokpolor, J. E., \& Omiunu, S. E. (2017). Role of career development services in developing students lifelong learning self-efficacy: Vocational and adult education lecturers' perceptions. Baltic Journal of Career Education and Management, 5(1), 30-45. Available at: https://doi.org/10.33225/bjcem/17.5.30.

Hisar, S. G. (2006). An experimental study on effective teaching methods that can be used in 4th and 5th grade English lessons. Doctoral Dissertation, Social Sciences.

İliç, U., \& Haseski, H. İ. (2019). Pre-service teachers' views on lifelong learning and adult education course. Aegean Journal of Education, 20(1), $51-66$. 
Kara, K., \& Karakoç, B. (2017). Evaluation of in-service training programs received by teachers in line with the 'eight process elements' in adult education. Journal of Bayburt Education Faculty, $12(24)$, 613-634.

Kılıc, C. (2014). Pre-service teachers' perceptions of lifelong learning. Journal of Education and Training Research, 3(4), 79-87.

Kıran, İ. (2008). Evaluation of public education centers in providing life-long education: The example of Yüreğir public education center. Unpublished Master Thesis, Gazi University, Institute of Educational Sciences, Ankara.

Knowles, M. S. (1980). The modern practice of adult education. From Pedagogy to Andragogy. New York: Association Press.

Knowles, M. S., \& Ayhan, S. (1996). Adult learners: An overlooked segment. Ankara, Turkey: Ankara University Press.

Knowles, M. S., Holton III, E. F., \& Swanson, R. A. (2005). The adult learner. The definitive in adult education and human resource development (6th ed.). California: Elsevier Inc.

Konokman, G. Y., Akay, C., \& Demircioğlu, T. (2015). The education faculty academicians' views on the European union lifelong learning projects. The Journal of International Social Research, 8(38), 773-790.

Mali, Y. C. G. (2017). Adult learners'experiences in learning English: A case study of two university students in Indonesia. IJOTL-TL: Indonesian Journal of Language Teaching and Linguistics, 2(2), 131-146. Available at: https://doi.org/10.30957/ijoltl.v2i2.280.

Mora, J. G. (2001). Lifelong learning policies in Spanish Universities. European Journal of Education, 36(3), 317-327. Available at: https://doi.org/10.1111/1467-3435.00070.

OECD. (2012). "Lifelong learning and adults", in education today 2013: The OECD perspective. Paris: OECD Publishing.

Patton, M. Q. (2014). Methods of qualitative research and evaluation (3rd ed.). Ankara: Pegem Academy.

Tam, M. (2012). Lifelong learning for elders in Hong Kong: Policy and practice. International Journal of Lifelong Education, $31(2)$, 157-170. Available at: https://doi.org/10.1080/02601370.2012.663805.

Walczak, R., \& Kálmán, A. (2018). Lifelong learning expectations of young academics-analysis of polish and hungarian technical universities. Foundations of Management, $1 O(1), 207-224$. Available at: https://doi.org/10.2478/fman-2018-0016.

Wu, R., \& Wu, R. (2014). Challenges of adults in learning english as a second language: Focus on Adult Education in China. Journal of Language Teaching and Research, 5(5), 1132-1138. Available at: https://doi.org/10.4304/jltr.5.5.1132-1138.

Yayla, D. (2009). Evaluation of the Turkish adult education system. Ankara: Ministry of Education Research and Development Department (EARGED).

Yazar, T. (2012). Target audience in adult education. Journal of Dicle University Institute of Social Sciences, 4(7), 21-30.

Yıldırım, A., \& Simşek, H. (2013). Qualitative research methods in social sciences (9th ed.). Ankara: Seçkin Publishing.

Yildrim, R., \& Akcay, R. C. (2017). Evaluation of managerial effectiveness of lifelong learning services according to continuing education center instructors. Dumlupinar University Journal of Educational Sciences Institute, 1(1), 40-63.

Zhou, H., \& Tu, C.-C. (2019). Impacts of learning content focus and collaborative learning on university teachers' lifelong learning. Journal of Workplace Learning, 31(7), 442-464. Available at: https://doi.org/10.1 108/jwl-05-2018-0073. 